\title{
Teeth morphology and dental sexual dimorphism of three species of the sandskate genus Psammobatis Günther, 1870 from the Brazilian coast (Rajiformes, Arhynchobatidae)
}

\author{
Álvaro Brum Neto ${ }^{1 *}$ \\ Carlos Alberto Santos de Lucena ${ }^{2}$ \\ Pontifícia Universidade Católica do Rio Grande do Sul \\ ${ }^{1}$ Escola de Ciências da Saúde e da Vida, Programa de Pós-Graduação em Ecologia e Evolução da Biodiversidade \\ ${ }^{2}$ Museu de Ciências e Tecnologia \\ Avenida Ipiranga, 6.681, CEP 90.619-900, Porto Alegre - RS, Brazil \\ * Corresponding author \\ alvarobrumneto@gmail.com
}

Submetido em 27/11/2019

Aceito para publicação em 12/05/2020

\section{Resumo}

Morfologia e dimorfismo sexual de dentes de três espécies de raias do gênero Psammobatis Günther, 1870 da costa brasileira (Rajiformes, Arhynchobatidae). Conjuntos de mandíbulas das raias Psammobatis extenta $(\mathrm{n}=10)$, P. lentiginosa (apenas indivíduos adultos, $\mathrm{n}=8)$ e $P$. rutrum (apenas indivíduos adultos, $\mathrm{n}=$ 10) foram examinados utilizando microscopia eletrônica de varredura. Os dentes das fêmeas das três espécies e os dos imaturos de P. extenta não apresentaram diferenças, todos com dentes esmagadores monocuspidados, com uma cúspide pequena ou ausente. A heterodontia monognática foi observada em espécimes adultos de ambos os sexos das três espécies analisadas. Espécimes imaturos de $P$. extenta e fêmeas das três espécies diferiram dos machos adultos por terem dentes esmagadores ao invés dos dentes agarradores dos machos, indicando heterodontia sexual. Os dentes dos machos de $P$. extenta são pontiagudos e bem pronunciados, com as cúspides arredondadas, enquanto os machos de $P$. rutrum e $P$. lentiginosa possuem cúspides elípticas e similares entre si. Espécimes imaturos de $P$. extenta possuem cúspides pequenas. Os dentes de $P$. lentiginosa apresentam um sulco longitudinal em sua face labial, um caráter aqui hipotetizado como uma condição derivada.

Palavras-chave: Atlântico Sul; Batoidea; Elasmobrânquios; Microscópio Eletrônico de Varredura; Raias

\section{Abstract}

Sets of jaws of the sandskates Psammobatis extenta $(\mathrm{n}=10)$, $P$. lentiginosa (only adult specimens, $\mathrm{n}=8$ ) and $P$. rutrum (only adult specimens, $\mathrm{n}=10$ ) were examined by scanning electron microscopy. Female teeth of the three species and those of the immature P. extenta did not show differences, all having monocuspid crushing teeth, with a small, unpronounced or absent cusp. Monognathic heterodonty was observed in adult specimens in both sexes of the three species analyzed. Immature P. extenta and females of the three species differed from the adult males in having a crushing as opposed to a clutching dentition, implying gynandric heterodonty. Teeth of males of P. extenta have pointed, well-pronounced, rounded cusps, whereas males of $P$. rutrum and $P$. lentiginosa have elliptical and similar cusps. Immature specimens of $P$. extenta have small cusps. Teeth of $P$. lentiginosa have a longitudinal sulcus on their labial face, a character herein hypothesized as a derived condition.

Key words: Batoids; Elasmobranchs; Rays; Scanning Electron Microscopy; South Atlantic 


\section{Introduction}

Species of Psammobatis Günther, 1870 are endemic to the eastern South Pacific and western South Atlantic coasts of South America, occurring from Rio de Janeiro, Brazil to Chile (EBERT; COMPAGNO, 2007). Eight species are recognized: Psammobatis rudis Günther, 1870 (type species), from the coasts of Argentina and Chile; P. bergi Marini, 1932, P. extenta (Garman, 1913), P. lentiginosa McEachran, 1983, and $P$. rutrum Jordan, 1891 from Rio de Janeiro to Rio Grande do Sul, Brazil, Uruguay and Argentina; $P$. normani McEachran, 1983 from Uruguay to Chile; $P$. parvacauda McEachran, 1983 Argentina; and P. scobina (Philippi, 1857) from Uruguay to Argentina (GOMES, 2002; GOMES et al., 2010; LAST et al., 2016). Species of Psammobatis feed on small invertebrates such as crustaceans, polychaetes, mollusks, and more rarely on small fishes; they are demersal and inhabit the continental shelves and slopes (MUTO et al., 2001; LAST et al., 2016).

Studies of species of Psammobatis are mostly limited to reproductive biology (e.g., BRACCINI; CHIARAMONTE, 2002; MARTINS; ODDONE, 2017), feeding habits (e.g., MUTO et al., 2001; MABRAGAÑA; COUSSEAU, 2004; BRACCINI; PEREZ, 2005) and geographical distribution (e.g., MENNI; STEHMANN, 2000; GOMES et al., 2010). Concerning sexual dimorphism, the unpublished study of Paragó (2001) analyzed $P$. extenta and $P$. rutrum and sex-related shape of the anterior margin of the disc; Barbini and Lucifora (2012) recorded the gynandric heterodonty in Psammobatis bergi and $P$. extenta, and Braccini and Chiaramonte (2002) sexrelated differences in measurement variables and in tooth morphology in both sexes of $P$. extenta to the reproductive habit of the species. Herman et al. (1995), in their extensive batoid study, observed the dentition of $P$. rudis as a gradient monognathic heterodonty and pointed out its sexual heterodonty as seen in adults only. The same authors affirm that ontogenetic heterodonty is present only in males by a low tooth cusp, which grows to large size in maturing specimens.
Sexual heterodonty, dignathic heterodonty (differences in tooth morphology between upper and lower jaw), and monognathic heterodonty (variation in the morphology of teeth from different positions on the same jaw) are well represented in cartilaginous fish (Elasmobranchii) (HERMAN et al., 1994; 1995; 1996). In batoids, gynandric heterodonty is mentioned in Rajidae, Hypanus sabinus (Lesueur 1824), Fontitrygon colarensis (Santos, Gomes \& Charvet-Almeida 2004), Dasyatidae, Dasyatis hypostigma Santos \& Carvalho 2004, Rhinobatidae, Zapteryx brevirostris (Müller \& Henle 1841), Urotrygonidae, Urotrygon microphthalmum Delsman 1941 (FEDUCCIA; SLAUGHTER, 1974; KAJIURA; TRICAS, 1996; SANTOS; CHARVET-ALMEIDA, 2007; RANGEL et al., 2014; 2016); gynandric, monognathic and ontogenetic heterodonty in Rhinobatidae, Aptychotrema rostrata (Shaw 1794) (GUTTERIDGE; BENNETT, 2014). In the Arhynchobatidae, monognathic, sexual, and ontogenetic heterodonty occurs in juvenile males of Pavoraja asperula (= Brochiraja asperula (Garrick \& Paul 1974)) (HERMAN et al., 1994); monognathic heterodonty in Pavoraja laxipella (= Insentiraja laxipella (Yearsley \& Last 1992)) and Notoraja tobitukai (Hiyama 1940) (HERMAN et al., 1996). Sexual heterodonty is seen in Psammobatis bergi, P. extenta, and Atlantoraja castelnaui (Miranda Ribeiro 1907), A. cyclophora (Regan 1903), A. platana (Günther 1880) (BARBINI; LUCIFORA, 2012; RANGEL et al., 2014).

In this study, three species of the genus Psammobatis ( $P$. extenta, $P$. lentiginosa and $P$. rutrum) were investigated to determine if they show sexual heterodonty and ontogenetic variation.

\section{Material and Methods}

Specimens examined belong to the following institutions: Instituto de Ciências Biológicas da Universidade Federal de Rio Grande (FURG), caught between August 2013 and August 2014, by commercial fishing off the coast of Rio Grande do Sul State, between latitudes $34^{\circ} 28^{\prime} \mathrm{S}$ and $31^{\circ} 29^{\prime} \mathrm{S}$, at depths from 40 to 142 
m; and Universidade do Estado do Rio de Janeiro, Rio de Janeiro (UERJ), captured off the coast of Cabo Frio, Rio de Janeiro State, between latitudes $22^{\circ} 40^{\prime} \mathrm{S}$ and $22^{\circ} 41^{\prime} \mathrm{S}$ at depths of 50 to $55 \mathrm{~m}$. Species identification and the measurements follow Paragó (2001) and Gomes et al. (2010). In the text and tables, the measurements are in $\mathrm{cm}$. The specimens from FURG were received with their ontogenetic stage determined by examining gonads and clasper (MARTINS; ODDONE, 2017). All immature specimens were from UERJ. Twenty-eight sets of jaws (both upper and lower) were prepared and examined by scanning electron microscopy (SEM).

For SEM, the dental plates were cleaned with soft toothbrushes with fine bristles and toothpaste. The samples were subsequently dehydrated in an alcohol series $(24 \mathrm{~h}$ in $70 \%, 30 \mathrm{~min}$ in $80 \%$, and $30 \mathrm{~min}$ in $90 \%$ ), dried in a $50^{\circ} \mathrm{C}$ oven, coated with gold ions, and photographed with a Philipps XL 30 SEM of the Central de Microscopia e Microanálise (LabCEMM - PUCRS). This technique, when applied to teeth of $P$. lentiginosa (males), caused the teeth to crack at the depression on the labial crown face (sulcus). Because of this, the term "sulcus" is maintained in the text even though the images reveal the cracks.

For comparisons and analyses, both upper and lower dental plates were examined for each set of jaws, and three regions from each were highlighted: left lateral, right lateral and symphysis, totaling six regions in each specimen. Each region was compared between males and females of the same species, as well available specimens of each ontogenetic stage (adult/ immature) and between species. The description of the teeth, including size, arrangement, morphology and number, follows Moss (1977) and Rangel et al. (2015), and the shape of the cusp (elliptical or circular) was inferred from the external shape of the tooth. The ratio between the length and width of the symphyseal teeth (an average of fourteen teeth measured in each dental plate) as a function of total length was plotted in graphs to show the relation between tooth development and sexual maturity (see Table 1).

Tooth measurements (Figure 1) follow Gutteridge and Bennett (2014). The dental formula follows Belleggia et al. (2014) and corresponds to the number of rows of teeth in each jaw (minimum and maximum numbers in upper jaw/minimum and maximum numbers in lower jaw).

\section{Results}

The size range of specimens examined is shown in Table 1. In all species, there was the occurrence of monognathic and gynandric heterodonty and absence of dignathic heterodonty.

\section{Immature specimens}

Immature individuals smaller than 20.0 TL (Figure 2A and 2B), both males and females, had monocuspid teeth of the crushing type, with a small cusp (symphyseal teeth) or lacking a cusp (lateral teeth), and a smooth lozenge-shaped crown with rounded margins. Lateral teeth had a greater distance in between (Figure 2C), whereas for symphyseal teeth this space was almost nonexistent.

TABLE 1: Morphometric data of examined specimens of Psammobatis. $\mathrm{N}=$ number of set of jaws - upper and lower -, $\mathrm{TL}=$ total length, $\mathrm{DW}=$ disc width.

\begin{tabular}{cccccccccc}
\hline Species & \multicolumn{3}{c}{ Immatures } & \multicolumn{2}{c}{ Adult females } & \multicolumn{2}{c}{ Adult males } \\
\hline & N & Range TL & $\begin{array}{c}\text { Range } \\
\text { DW }\end{array}$ & N & Range TL & Range DW & N & Range TL & Range DW \\
\hline P. extenta & 3 & $15.0-18.0$ & $7.8-9.5$ & 3 & $24.8-29.5$ & $14.7-16.0$ & 4 & $26.0-31.7$ & $14.0-18.5$ \\
P. lentiginosa & 0 & 0 & 0 & 2 & $43.0-46.6$ & $24.0-26.7$ & 6 & $42.8-48.4$ & $25.0-28.0$ \\
P. rutrum & 0 & 0 & 0 & 2 & $27.5-27.5$ & $16.5-17.0$ & 8 & $22.5-28.5$ & $13.6-16.5$ \\
\hline
\end{tabular}


FIGURE 1: Psammobatis extenta FURG (not numbered), $24.8 \mathrm{~cm}$ TL, adult female, Rio Grande do Sul State, Brazil, upper jaw, symphyseal region. Horizontal axis (blue arrow) $=$ tooth width, vertical axis (yellow arrow) $=$ tooth length.

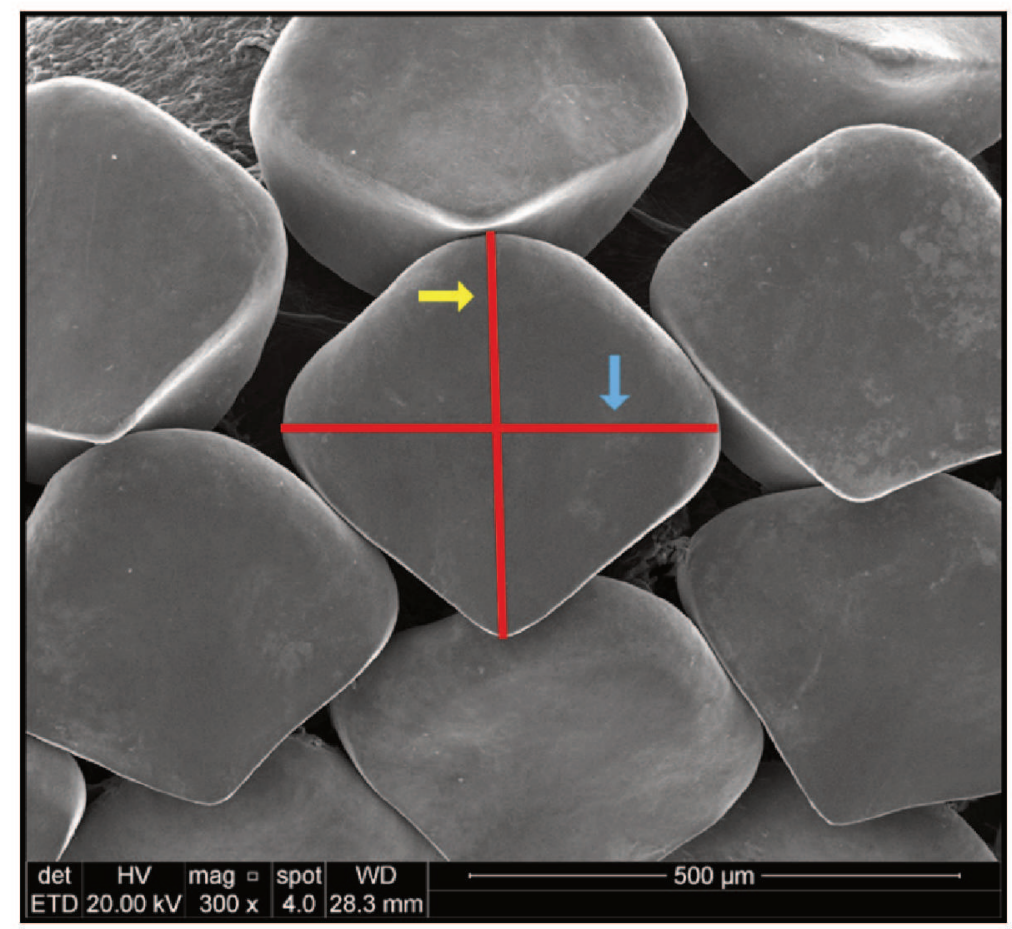

FIGURE 2: (A) Psammobatis extenta UERJ (not numbered), $15.0 \mathrm{~cm}$ TL, immature female, Rio de Janeiro State, Brazil. Occlusal view, upper dental plate, right region. (B) $P$. extenta UERJ (not numbered), $18.0 \mathrm{~cm}$ TL, immature male, Rio de Janeiro State, Brazil. (C) P. extenta UERJ (not numbered), $17.5 \mathrm{~cm}$ TL immature female, Rio de Janeiro State, Brazil. Occlusal view, upper dental plate, left lateral region.

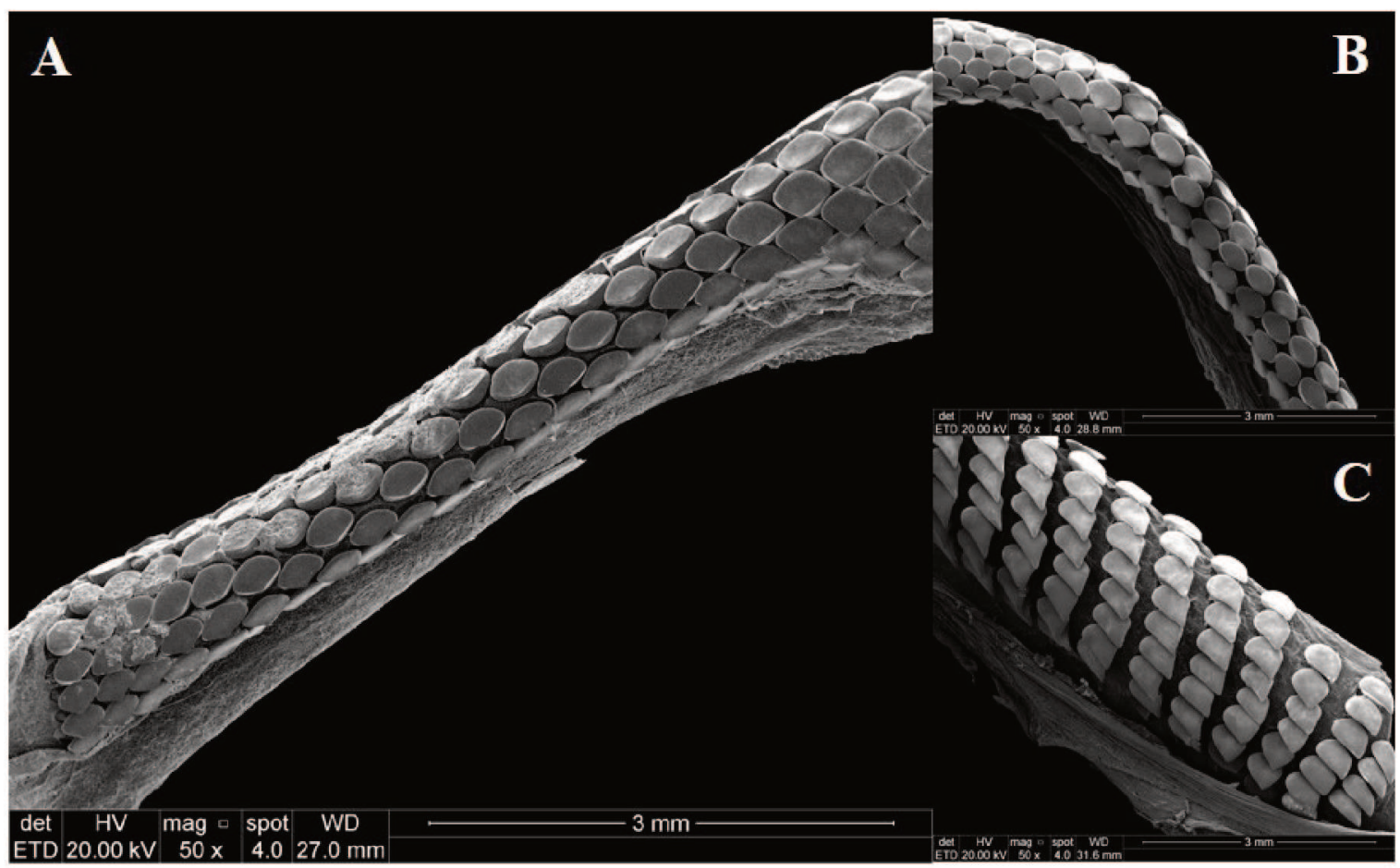


The length/width ratio of the symphyseal teeth varied from 0.9 to 1.1 in immature specimens, as seen in Figure 3A. This figure shows that the symphyseal cusps of immature and female specimens are smaller than those of adult males. Dental formula was: P. extenta, immature specimens, 16-20/17-20 $(n=3)$.

\section{Adult females}

Adult females of all species between 24.0 and 44.0 TL (Figure 4) had monocuspid teeth of the crushing type, with a small cusp (symphyseal teeth) or lacking a cusp (lateral teeth), and a smooth lozenge-shaped crown with rounded margins. The length/width ratio of the symphyseal teeth varied in adult females of $P$. extenta (Figure 3A); from 0.7 and 0.8 in P. lentiginosa
(Figure 3B), and from 0.9 and 1.0 in P. rutrum (Figure $3 \mathrm{C}$ ). Figure 3 shows that the symphyseal cusps of female specimens are smaller than the adult males in all three species. Dental formula was: $P$. extenta, 19-23/20-23 $(\mathrm{n}=3) ;$ P. lentiginosa, 22-24/23-24 $(\mathrm{n}=2)$; and P. rutrum, 27-28/27-28 $(\mathrm{n}=8)$.

\section{Adult males}

\section{Psammobatis extenta}

Monocuspid teeth of the clutching type, with pointed and well-pronounced cusps, especially those of the symphyseal region, which had a perpendicular orientation and were smooth and rounded (Figure 5A). Crown was smooth and lozenge-shaped, and

FIGURE 3: (A) The length/width ratio of symphyseal teeth (STL/STW) as a function of total length of Psammobatis extenta. (B) The length/width ratio of symphyseal teeth (STL/STW) as a function of total length of Psammobatis lentiginosa. (C) Ratio of the length/width symphyseal teeth (STL/STW) as a function of total length of Psammobatis rutrum. Females - red squares; males - blue triangles; immatures - green circles (if shown).

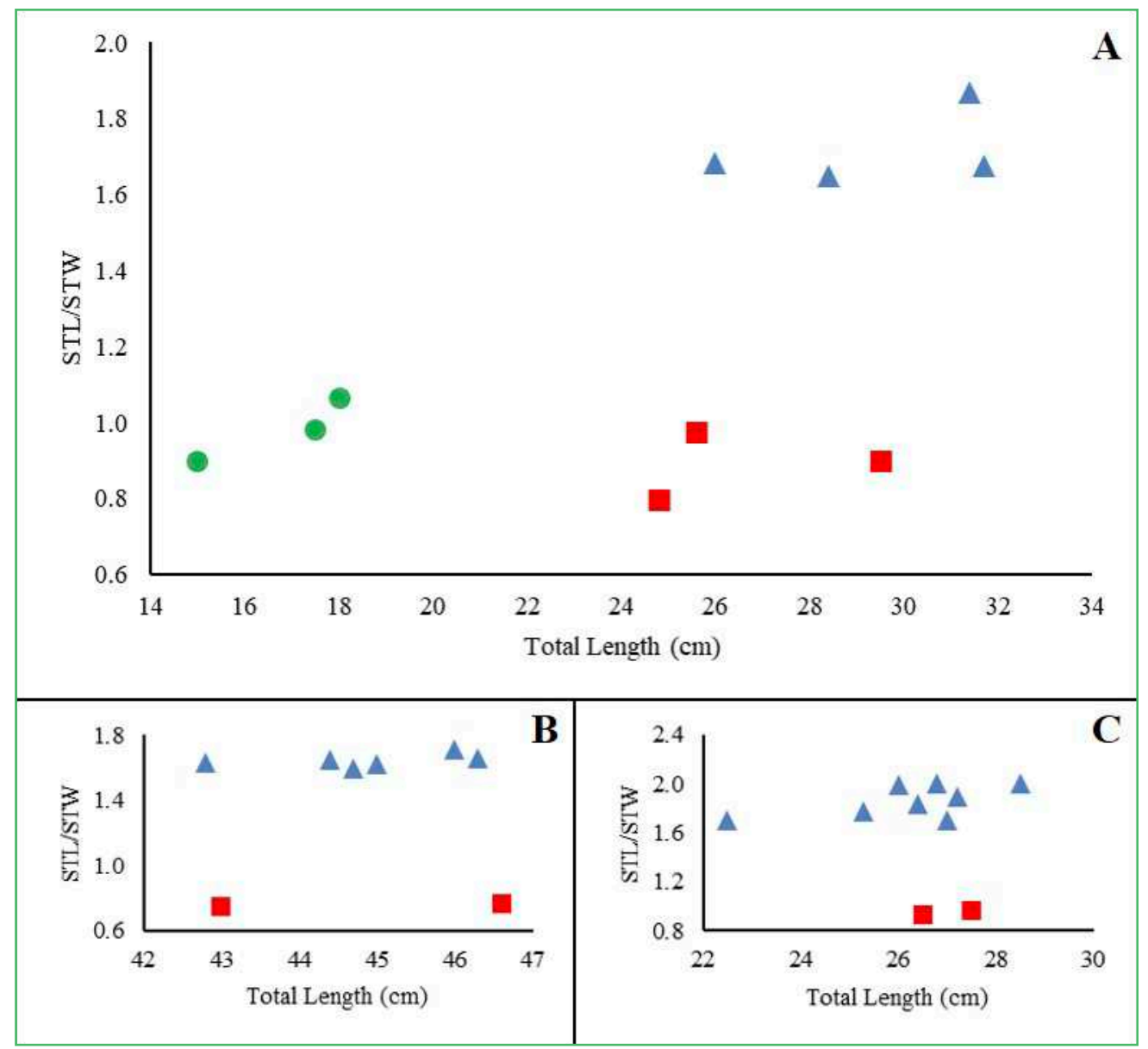


FIGURE 4: (A) Psammobatis extenta FURG (not numbered), $29.5 \mathrm{~cm}$ TL, adult female, Rio Grande do Sul State, Brazil. Occlusal view, upper dental plate, left lateral region. (B) P. lentiginosa FURG (not numbered), $44.0 \mathrm{~cm}$ TL, adult female, Rio Grande do Sul State, Brazil. Occlusal view, upper dental plate, left lateral region. (C) P. rutrum FURG (not numbered), $27.5 \mathrm{~cm}$ TL, adult female, Rio Grande do Sul State, Brazil. Occlusal view, upper dental plate, symphyseal region.

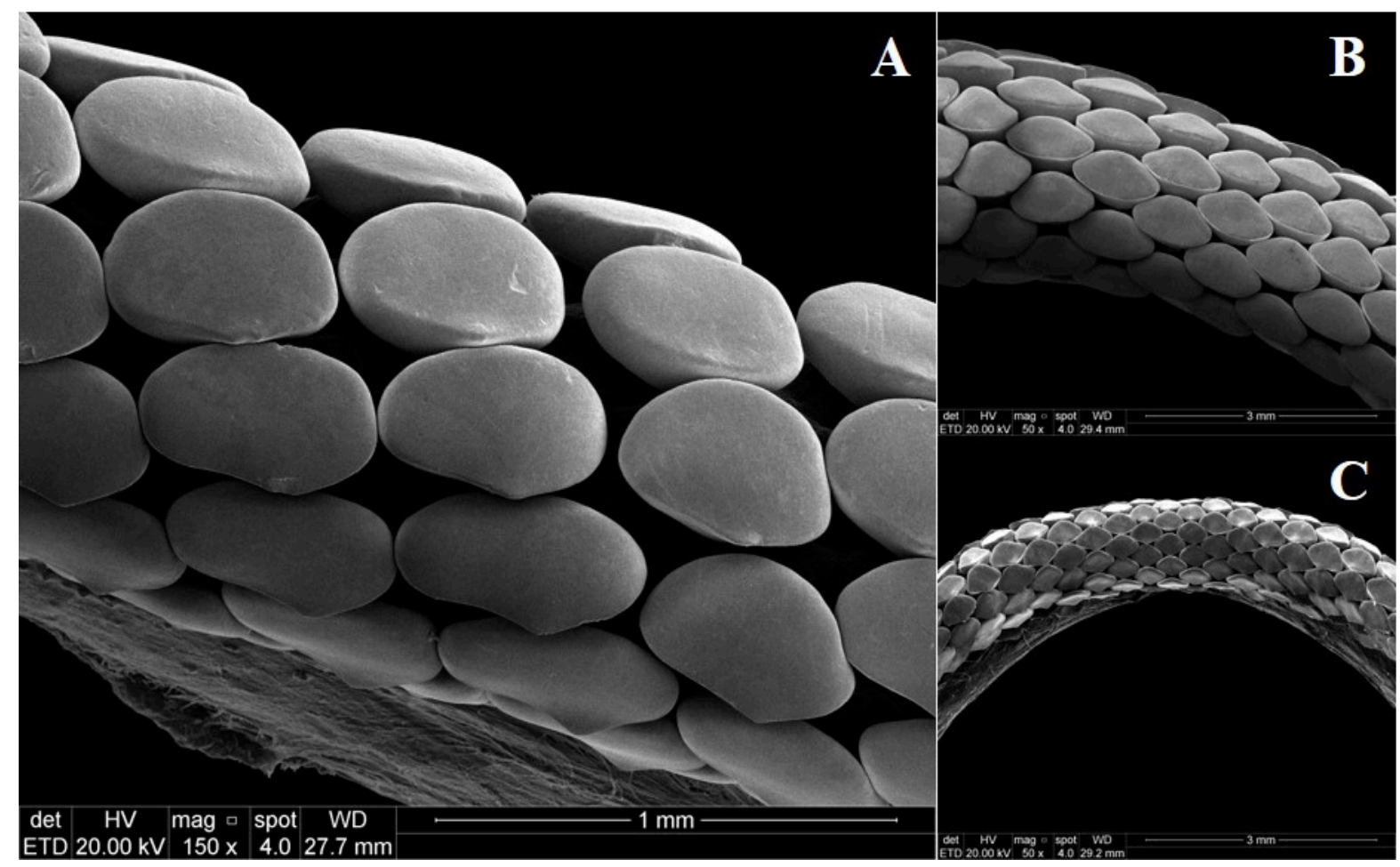

with rounded margins. Monognathic heterodonty was observed in all adult male specimens. In males larger than $30 \mathrm{TL}$, the lateral teeth had cusps that varied from short to well-developed, even though most teeth were morphologically similar. Specimens smaller than $28 \mathrm{TL}$ had fewer teeth with developed cusps in comparison with larger males, as their lateral regions had only poorly developed cusps (Figure 5B). The length/width ratio of symphyseal teeth varied from 1.7 to 1.9 (Figure 3A). Dental formula was 19-23/20-23 $(n=3)$.

\section{Psammobatis lentiginosa}

Monocuspid teeth were of the clutching type, with pointed and well-pronounced cusps, especially on symphysis, with a perpendicular orientation, a longitudinal sulcus on the apical face, and elliptical shape (Figure 5C). Crown was smooth, lozenge-shaped, and had rounded margins (Figure 5D). Monognathic heterodonty was observed in all adult males. In specimens greater than $48 \mathrm{TL}$, the jaws had morphologically similar teeth, with lateral teeth having short to developed cusps. Specimens smaller than 47 TL have fewer teeth with developed cusps in comparison with larger males, as their lateral regions had only poorly developed cusps (Figure 5E). The length/width ratio of symphyseal teeth ranged from 1.6 to 1.7 (Figure 3B). Dental formula was $21-22 / 21-23(n=6)$.

\section{Psammobatis rutrum}

Monocuspid teeth were of the clutching type, with pointed and well pronounced cusps, especially on symphysis, with a perpendicular orientation, smooth and elliptical (Figure 5F). Crown was smooth, lozenge-shaped and had rounded margins. Monognathic heterodonty was observed in all adult males. Specimens smaller than 28 TL had fewer teeth with developed cusps in comparison with larger males, since their lateral regions had only poorly developed cusps (Figure $5 \mathrm{G})$. In specimens greater than $30 \mathrm{TL}$, all teeth had developed cusps; the largest cusps always occurred 
FIGURE 5: (A) Psammobatis extenta FURG (not numbered), $26.0 \mathrm{~cm}$ TL, adult male, Rio Grande do Sul State, Brazil. Occlusal view, upper dental plate, symphyseal region. (B) P. extenta FURG (not numbered), $17.2 \mathrm{~cm}$ TL, adult male, Rio Grande do Sul State, Brazil. Occlusal view, lower dental plate, right region. (C) Psammobatis lentiginosa FURG (not numbered), $48.4 \mathrm{~cm}$ TL, adult male, Rio Grande do Sul, State, Brazil. Occlusal view, upper dental plate, symphyseal region. (D) P. lentiginosa FURG (not numbered), $46.3 \mathrm{~cm}$ TL, adult male, Rio Grande do Sul, State. Occlusal view, upper dental plate, symphyseal region and (E) occlusal view, upper dental plate, right lateral region. (F) Psammobatis rutrum FURG (not numbered), $25.5 \mathrm{~cm}$ TL, adult male, Rio Grande do Sul, State, Brazil. Occlusal view, lower dental plate, symphyseal region. (G) P. rutrum FURG (not numbered), $26.0 \mathrm{~cm}$ TL, adult male, Rio Grande do Sul State, Brazil. Occlusal view, lower dental plate, right lateral region.

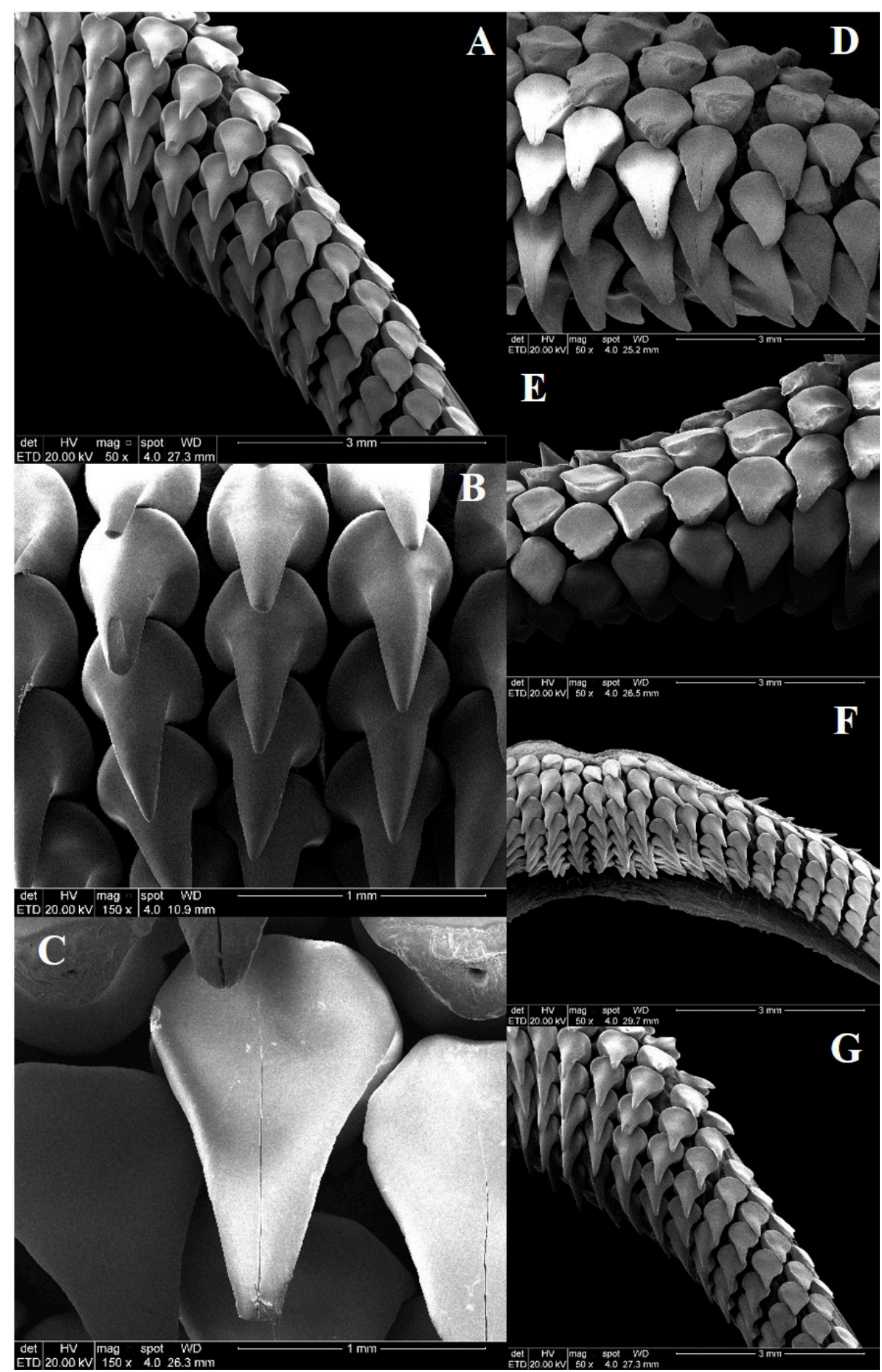


in the symphyseal region. The length/width ratio of symphyseal teeth ranged from 1.7 and 2.0 (Figure 3C). Dental formula was $25-27 / 25-27(n=8)$.

\section{Discussion}

Adults of the species examined showed monognathic heterodonty, mainly in the anterior teeth (symphyseal) when compared to the lateral ones. Females of the three species were differentiated from adult males by having a crushing type of dentition as opposed to a clutching type of dentition in males, thus indicating also a gynandric heterodonty. Specimens of $P$. extenta also showed ontogenetic heterodonty with the immature males showing monocuspid teeth of the crushing type, with a negligible or lacking cusp; while adult males had monocuspid teeth of the clutching type, with pointed and well-pronounced cusps, especially those of the symphyseal region.

This ontogenetic heterodonty is related to different feeding habits regarding $P$. extenta. It is in line with Barbini and Lucifora (2012) who mentioned that "small individuals consume amphipods and small crabs, and that large individuals consume cumaceans [small crustaceans] and isopods". Muto et al. (2001) and Braccini and Perez (2005) also analyzed diets and found no differences between adult males and adult females. However, the ontogenetic and seasonal patterns seem in feeding habits correlated with the skate's body size and prey availability, respectively; and these features seem to be of more importance to the species' ecological role.

The development of the cusp of males' teeth of all three species coincides with sexual maturity: between 25 and 26 TL for $P$. extenta and P. rutrum and between 40 and 42 TL for $P$. lentiginosa (GOMES et al., 2010; PERIER et al., 2011; MARTINS; ODDONE, 2017). The analysis of the length/width ratio of symphyseal teeth in the adults of the three species examined here (Figure 3) demonstrated that teeth in males can be almost twice as long as wide. This does not occur in adult females of the three species or in the immature specimens of $P$. extenta, in which the ratio is close to 1 . The variations in tooth shape in males, related to length/width ratio and the respective size range and sex, support the hypothesis that the observed gynandric heterodonty is related to the mating strategies. This same pattern was found for $P$. bergi and P. extenta (BARBINI; LUCIFORA, 2012). The relationship between sexual maturation and development of teeth in males is also reported for Amblyraja doellojuradoi (Pozzi 1935) (Rajidae) (DELPIANI et al., 2012), Aptychotrema rostrata (Shaw 1794) (Trygonorrhinidae) (GUTTERIDGE; BENNETT, 2014), Atlantoraja cyclophora (Regan 1903) (Arhynchobatidae) (OLIVEIRA; ODDONE, 2012; RANGEL et al., 2015), and Hypanus sabinus (Leuseur 1824) (Dasyatidae) (KAJIURA; TRICAS, 1996; KAJIURA et al., 2000); in all these cases, males exhibit a copulatory behavior of "hugging" females with their jaws. A. doellojuradoi and $H$. sabinus show differences in diets between males and females, but $A$. rostrata and $A$. cyclophora seem to have a narrower niche, as males and females have a significant overlap in their feeding habitats (KAJIURA; TRICAS, 1996; KYNE; BENNETT, 2002; DELPIANI et al., 2013; VIANA; VIANNA, 2014).

Regarding their taxonomy, $P$. extenta is differentiated from $P$. rutrum by their dental formula (33-46 tooth rows on upper jaw vs 50-54 and 42-45, respectively) and from $P$. lentiginosa by the shape of the cusp (circular, rounded shaped vs elliptical). McEachran (1983) reported 36-50 upper tooth rows and used this range to distinguish $P$. glansdissimilis McEachran $(=P$. extenta $)$ from $P$. rutrum, which possesses 43-66. Braccini and Chiaramonte (2002) recorded for $P$. extenta 34-46 rows of teeth in the upper jaw in both sexes. P. lentiginosa is distinguished from $P$. rutrum and $P$. extenta by the presence of a sulcus on the apical face, which is absent in the latter species. These new data may help in the discrimination of these species, since they are morphologically very similar. Comparing the dental formulas of immature and adults of $P$. extenta, the number of tooth rows appears to increase proportionally to specimen size, as suggested for this species by Braccini and Chiaramonte (2002) and for Mustelus henlei (Gill 1863) by Bellenggia et al. (2014). Unfortunately, immature individuals of $P$. lentiginosa and P. rutrum were not available for this study, but comparing small adults (approx. 44 TL and 
25 TL for $P$. lentiginosa and $P$. rutrum, respectively) with large adults (approx. $47 \mathrm{TL}$ and $28 \mathrm{TL}$ for $P$. lentiginosa and $P$. rutrum, respectively) the pattern seems to be the same as in $P$. extenta.

The sulcus on the apical face of the teeth of $P$. lentiginosa not seen in other Psammobatis or related species so far, is present in a similar condition in Dasyatis hypostigma (RANGEL et al., 2014). Morphological (MCEACHRAN; DUNN, 1998) and molecular (NAYLOR et al., 2016) analyses have shown that Dasyatidae is not closely related to Arhynchobatidae, which leads us to assume that the presence of a sulcus is most parsimoniously interpreted as having occurred independently in D. hypostigma and P. lentiginosa.

\section{Acknowledgments}

AB thanks Wagner Prates of LabCEMM PUCRS for help in taking SEM photographs, Rafael Gazzana for editing the images, and Bianca Rangel for help concerning methods. We thank Marcelo Carvalho for sending important references, Maria Cristina Oddone (Universidade Federal de Rio Grande) and Ulisses Gomes (Universidade do Estado do Rio de Janeiro) for the loan of specimens, essential for the undertaking of this study, and all colleagues who contributed to the improvement of this manuscript. AB thanks the Postgraduate Program in Ecology and Evolution of Biodiversity for the CNPq scholarship.

\section{References}

BARBINI, S. A.; LUCIFORA, L. O. Ontogenetic diet shifts and food partitioning between two small sympatric skates (Chondrichthyes, Rajidae) in the Southwestern Atlantic. Marine and Freshwater Research, Collingwood, v. 63, p. 905-913, 2012.

BellegGiA, M.; FigueroA, D. E.; BREMEC, C. S. The dentition of the narrownose smooth-hound shark, Mustelus schmitti. Marine and Freshwater Research, Collingwood, v. 65, p. $688-696,2014$.

BRACCINI, J. M.; CHIARAMONTE, G. E. Reproductive biology of Psammobatis extenta. Journal of Fish Biology, Haboken, v. 61, p. 272-288, 2002.

BRACCINI, J. M., PEREZ, J. E. Feeding habits of the sandskate Psammobatis extenta (Garman, 1913): sources of variation in dietary composition. Marine and Freshwater Research, Collingwood, v. 56, p. 395-403, 2005.
DELPIANI, G.; FIGUEROA, D.; MABRAGAÑA, E. Dental abnormalities of the southern thorny skate. Revista de Biología Marina y Oceanografía, Viña del Mar, v. 47, p. 135-140, 2012.

DELPIANI, G. E.; SPATH, M. C.; FIGUEROA, D. E. Feeding ecology of the southern thorny skate, Amblyraja doellojuradoi on the Argentine Continental Shelf. Journal of the Marine Biological Association of the United Kingdom, Cambridge, v. 93, p. $2207-$ 2216, 2013

EBERT, A. D.; COMPAGNO, L. J. V. Biodiversity and systematic of skates (Chondrichthyes: Rajiformes: Rajoidei). Environmental Biology of Fisheries, Berlin, v. 80, p. 111-124, 2007.

FEDUCCIA, A.; SLAUGHTER, B. H. Sexual dimorphism in skates (Rajidae) and its possible role in differential niche utilization. Evolution, New York, v. 28, p. 164-168, 1974.

GOMES, U. L. Revisão taxonômica da família Rajidae no Brasil (Chondrichthyes, Elasmobranchii, Rajiformes). 2002. 286 f. Tese (Doutorado em Zoologia) - Universidade Federal do Rio de Janeiro, Rio de Janeiro. 2002.

GOMES, U. L.; SIGNORI, C. N.; GADIG, O. B. F.; SANTOS, H. R. S. Guia para identificação de tubarões e raias do Rio de Janeiro. Rio de Janeiro: Technical Books, 2010. 234 p.

GUTTERIDGE, A. N.; BENNETT, M. B. Functional implications of ontogenetically and sexually dimorphic dentition in the eastern shovelnose ray, Aptychotrema rostrata. The Journal of Experimental Biology, Cambridge, v. 217, p. 192-200, 2014.

HERMAN, J.; HOVESTADT-EULER, M.; HOVESTADT, D. C. Contributions to the study of the comparative morphology of teeth and other relevant ichthyodorulites in living supra-specific taxa of Chondrichthyan fishes: addendum to part A.1. Order: Hexanchiformes - Family: Hexanchidae. Odontological results supporti. In: STEHMANN, M. (Ed.). Contributions to the study of the comparative morphology of teeth and other relevant ichthyodorulites in living supraspecific taxa of chondrichthyan fishes. Vol. 64. Brussels: Bulletin de l'Institut Royal des Sciences Naturelles de Belgique, Biologie, 1994. p. 147-163.

HERMAN, J.; HOVESTADT-EULER, M.; HOVESTADT, D. C. Part B: Batomorphii. No. 1b: Order: Rajiformes - Suborder Rajoidei - Family: Rajidae; Genera and Subgenera: Bathiraja (with a DeepWater, Shallow-Water and Transitional Morphotype), Psammobatis, Raja (Amblyraja), Raja (Dipturus), Raja (Leucoraja), Raja (Raja), Raja (Rajella), Raja (with Two Morphotypes), Raja (Rioraja), Raja (Rostroraja), Raja lintea, and Sympterygia." In: STEHMANN, M. (Ed.). Contributions to the study of the comparative morphology of teeth and other relevant ichthyodorulites in living supraspecific taxa of chondrichthyan fishes. Vol. 65. Brussels: Bulletin de l'Institut Royal des Sciences Naturelles de Belgique, Biologie, 1995. p. 237-307.

HERMAN, J.; HOVESTADT-EULER, M.; HOVESTADT, D. C.; STEHMANN, M. "Part B: Batomorphii № 1c: Order Rajiformes-Suborder Rajoidei-Family: Rajidae-Genera and Subgenera: Arhynchobatis, Bathyraja richardsoni-type, Cruriraja, Irolita, Notoraja, Pavoraja (Insentiraja), Pavoraja (Pavoraja), Pseudoraja, Raja (Atlantoraja), Raja”. In: STEHMANN, M. (Ed.). Contributions to the study of the comparative morphology of teeth and other relevant ichthyodorulites in living supraspecific taxa of chondrichthyan fishes. Vol. 65. Brussels: Bulletin de 
l'Institut Royal des Sciences Naturelles de Belgique, Biologie, 1996. p. 179-236.

KAJIURA, S. M.; SEBASTIAN, A. P.; TRICAS, T. C. Dermal bite wounds as indicators of reproductive seasonality and behaviour in the Atlantic stingray, Dasyatis sabina. Environmental Biology of Fishes, Berlin, v. 58, p. 23-31, 2000.

KAJIURA, S. M.; TRICAS, T. C. Seasonal dunamics of dental sexual dimorphism in the Atlantic stingray Dasyatis sabina. The Journal of Experimental Biology, Cambridge, v. 199, p. 2297 2306, 1996.

KYNE, P. M.; BENNETT, M. B. Diet of the eastern shovelnose ray, Aptychotrema rostrata (Shaw \& Nodder, 1794), from Moreton Bay, Queensland, Australia. Marine and Freshwater Research, Collingwood, v. 53, n. 3, p. 679-686, 2002.

LAST, P. R.; STEHMANN, M. F. W.; SÉRET, B.; WEIGMANN, S. Softnose skates. Family Arhynchobatidae. In: LAST, P. R.; WHITE, W. T.; CARVALHO, M. R. de; SÉRET, B.; STEHMANN, M. W.; NAYLOR, J. P. (Ed.). Rays of the world. Ithaca: CSIRO Publishing, 2016. p. 364-472.

MABRAGAÑA, E.; COUSSEAU, M. B. Reproductive biology of two sympatric skates in the south-west Atlantic: Psammobatis rudis and Psammobatis normani. Journal of Fish Biology, Haboken, v. 65, p. 559-573, 2004.

MARTINS, M. F.; ODDONE, M. C. Reproductive biology of Psammobatis rutrum (Chondrichthyes: Arhynchobatidae) in south Brazil, south-west Atlantic. Journal of Fish Biology, Haboken, v. 91, p. 443-459, 2017.

MCEACHRAN, J. D. Results of the research cruises of frv walther herwig to south-america. 61. Revision of the south-american skate genus Psammobatis Gunther, 1870 (Elasmobranchii, Rajiformes, Rajidae). Archiv fur Fischereiwissenschaft, Berlin, v. 34, p. 23$80,1983$.

MCEACHRAN, J. D.; DUNN, K. A. Phylogenetic analysis of skates, a morphologically conservative clade of elasmobranchs (Chondrichthyes: Rajidae). Copeia, Lawrence, v. 1998, n. 2, p. 271-290, 1998 .

MENNI, R. C.; STEHMANN, M. F. W. Distribution, environment and biology of batoid fishes of Argentina, Uruguay and Brazil. A review. Revista del Museo Argentino de Ciencias Naturales, Buenos Aires, v. 2, p. 69-109, 2000.

MOSS, S. A. Feeding mechanisms in sharks. American Zoologist, McLean, v. 175, p. 355-364, 1977.

MUTO, E. Y.; SOARES, L. S.; GOITEIN, R. Food resource utilization of the skates Rioraja agassizii (Müller; Henle, 1841) and Psammobatis extenta (Garman, 1913) on the continental shelf of Ubatuba, South-eastern Brazil, Brazilian Journal of Biology, São Carlos, v. 61, p. 217-238, 2001.
NAYLOR, G. J. P.; YANG, L.; CORRIGAN, S.; CARVALHO, M. D. Phylogeny and classification of rays. In: LAST, P. R.; WHITE, W. T.; CARVALHO, M. R de.; SÉRET, B.; STEHMANN, M. W.; NAYLOR, J. P. (Ed.). Rays of the world. Ithaca: CSIRO Publishing, 2016. p. 10-15.

OLIVEIRA, M. A.; ODDONE, M. C. La dentición heterodonta en rayas (Chondrichthyes: Rajiformes): caso de estudio en el género Atlantoraja Menni, 1972. In: CONGRESSO URUGUAYO DE ZOOLOGIA, II, 2012, Montevideo. Resúmenes... Montevideo: Facultad de Ciencias, 2012. Versão eletrônica.

PARAGÓ, C. L. D. P. Contribuição à taxonomia do gênero Psammobatis Günther, 1870 (Chondrichthyes, Rajidae): caracterização das espécies do subgrupo I de McEachran (1983) com base em padrões de coloração e espinulação. 2001. 52 f. Dissertação (Mestrado em Zoologia) - Museu Nacional Rio de Janeiro, Rio de Janeiro. 2001.

PERIER, R.; ESTALLES, M.; COLLER, M.; DI GIACOMO, E. E. Reproductive biology of the endemic skate Psammobatis lentiginosa in the San Matías Gulf (south-western Atlantic). Journal of the Marine Biological Association of the United Kingdom, Cambridge, v. 91, p. 1165-1173, 2011.

RANGEL, B.; MARINHO, J.; MALAVASI-BRUNO, C.; AMORIM, A.; KFOURY JUNIOR, J. R.; RICI, R. Dimorfismo sexual da raia-santa Atlantoraja cyclophora: aspectos morfológicos. Revista Ceciliana, Santos, v. 7, p. 9-12, 2015.

RANGEL, B.; RODRIGUES, S. S.; FAVARON, P. O.; AMORIM, A. F.; RICI, R. Structure and dental sexual dimorphism in Dasyatis hypostigma (Santos; Carvalho, 2004) (Myliobatiformes, Dasyadae). In: MÉNDEZ-VILlAS, A. (Ed.), Microscopy - Advances in scientific research and education. Badajoz: Formatex Research Center, p. 89-94, 2014.

RANGEL, B.; SANTANDER-NETO, J.; RICI, R. E. G.; LESSA, R. Dental sexual dimorphism and morphology of Urotrygon macrophathalmum. Zoomorphology, Berlin, v. 135, p. 367-374, 2016.

SANTOS, H. R. S.; CHARVET-ALMEIDA, P. Description of females of the stingray Dasyatis colarensis Santos, Gomes \& Charvet-Almeida, 2004 (Chondrichthyes, Myliobatiformes, Dasyatidae). Arquivos do Museu Nacional, Rio de Janeiro, v. 65, p. 19-25, 2007.

VIANA, A. F.; VIANNA, M. The feeding habits of the eyespot skate Atlantoraja cyclophora (Elasmobranchii: Rajiformes) in southeastern Brazil. Zoologia, Curitiba, v. 31, p. 119-125, 2014. 